\title{
Equity Ownership and Capital Structure: Evidence from the Firms in the Nikkei 225 Stock Index
}

\author{
Chikashi Tsuji ${ }^{1}$ \\ ${ }^{1}$ Faculty of Economics, Chuo University, Tokyo, Japan \\ Correspondence: Chikashi Tsuji, Faculty of Economics, Chuo University, 742-1 Higashinakano Hachioji-shi, \\ Tokyo 192-0393, Japan. Tel: 81-42-674-2211. E-mail: mail_sec_low@minos.ocn.ne.jp
}

Received: December 2, 2013

Accepted: December 21, 2013

Online Published: February 25, 2014

doi:10.5539/ijef.v6n3p55

URL: http://dx.doi.org/10.5539/ijef.v6n3p55

\begin{abstract}
In this paper, we research the linkage between the equity ownership and debt ratios as to the corporations in the Nikkei 225 stock index in Japan. The findings with regard to the Nikkei 225 firms from our investigations are as follows. First, we clarify that the relations between debt ratios and the shareholding ratios of foreign companies are strongly negative. Second, we also reveal that the relations between debt ratios and the shareholding ratios of the domestic non-financial corporations are strongly positive. Third, we further derive that the relations between debt ratios and the shareholding ratios of the 10 largest shareholders are generally negative.
\end{abstract}

Keywords: capital structure, equity ownership, debt ratio, Nikkei 225, panel data analysis

\section{Introduction}

Is corporate equity ownership related to the corporate capital structure? If larger shares are held by foreign companies or investors, outside governance would be strong, and then because of the pressure to maintain their high financial strength, is capital adequacy ratio higher in such firms? On the other hand, if larger shares are held by the domestic companies stably, outside governance would be weak, and as a result, is capital adequacy ratio lower in such firms? If this kind of mechanism and prediction hold, corporate equity ownership and capital structure shall be strongly related.

With respect to the related preceding studies, conflicts of interest between managers and outside shareholders lie at the heart of the corporate governance literature as the famous papers by Jensen and Meckling (1976) and Shleifer and Vishny (1986) demonstrated. While there exists the literature with regard to the effects of ownership on corporate performance as Morck et al. (1988), McConnell and Servaes (1990), and Himmelberg et al. (1999) exhibited, however, the linkage between ownership structure and corporate leverage remains largely uninvestigated. Further, although there are recent international researches in this area such as those by Baker and Wurgler (2002) for US firms, Short et al. (2002) for UK firms, Brailsford et al. (2002) for Australian firms, and King and Santor (2008) for Canadian firms. However, according to our reviews of existing literature, there seems to be little study as to the linkage between corporate leverage and the corporate equity ownership by focusing on the states of Japan. Hence presenting the empirical results by utilizing the Japanese data is meaningful to contribute to the body of the academic international researches described above.

Considering the states of the preceding studies as reviewed above and our motivation, our objective in this paper is for empirically exploring the linkage between equity ownership and corporate capital structure. More specifically, the focus of our study is on the equity ownership and the corporate debt ratios with regard to the corporations in the Nikkei 225 stock index in Japan. The contributions derived from our studies can be summarized as follows. First, our investigations find that the relations between debt ratios and the shareholding ratios of foreign companies are strongly negative. Second, we reveal that the relations between debt ratios and the shareholding ratios of the domestic non-financial corporations are strongly positive. Third, we also derive that the relations between debt ratios and the shareholding ratios of the 10 largest shareholders are generally negative. Finally, we evidence that the relations between debt ratios and the shareholding ratios of board of the directors are unclear.

The organization of the paper is as follows. After Section 1, Section 2 attempts to discuss some reasonable predictions on our focusing issues, Section 3 describes the data and models for our investigations, Section 4 
documents our empirical evidence and the interpretations, and Section 5 summarizes the paper.

\section{Several Discussions}

First, we attempt to discuss the relationship between equity ownership and corporate debt ratios from several viewpoints in this section. We note that the Japanese firms have such a well-known characteristic as cross-shareholding, thus it is particularly important to consider the effects of equity ownership structure on corporate financial structure in Japan. First, if the shareholding ratios of foreign companies or investors are higher, the firms would be tightly watched by the so-called smart money, thus the firms would be considered to have sound financial stability or solvency. As a result, the firms therefore would have higher capital adequacy ratios, namely lower debt ratios. Next, with regard to the shareholding ratios of the domestic non-financial corporations, the higher values of the ratios mean the higher cross-shareholdings, which are one of the outstanding characteristics of the corporate ownership in Japan. In general, the firm with higher ratio of the cross-shareholdings would be less exposed to the market monitoring, thus motivation of building sound financial structure would be relatively low. As a result, the firms with high shareholding ratios of the domestic non-financial corporations would have low capital adequacy ratios, namely high debt ratios.

Further, regarding the shareholding ratio of the 10 largest shareholders, it would be similar to the cross-shareholding ratio. Namely, the higher shareholding ratios of the 10 largest shareholders would mean lower capital soundness and higher debt ratios from the viewpoint of outside governance. Finally, regarding the shareholding ratio of board of the directors, if the board of directors is highly motivated for managing companies successfully by possessing larger portion of their firms, it would lead the higher capital adequacy ratio. On the other hand, however, if the larger shareholdings by the board of the directors function as the cross-shareholdings argued above, it may lead to higher debt ratios because of the weak outside governance. Hence the direction of the effects of shareholdings of the board of the directors on capital structure should be examined by data to understand the states of the real-world.

As discussed above, some reasonable relations between corporate equity ownership and the capital structure are derived; however, it needs careful empirical examinations to verify the actual relations in the real-world. Hence, from the next section, we attempt to perform the empirical analyses on this issue by using the data of the Japanese firms.

\section{Data and Models}

The data used in this study are the corporate balanced and unbalanced panel data. Our sample period spans from 1986 to 2011 (fiscal year). Our focus is on the firms in the Nikkei 225, whose data are available for constructing all variables, and our data for the analyses in this paper are supplied by the Quick Corp. In addition, this paper utilizes the balanced and unbalanced pooled regression models. In our models, as we describe in details later, the dependent variables are the next year's total debt (book-value) to total asset (book-value) ratio (the variable, $\mathrm{D} / \mathrm{A}(t+1))$ and the next year's total debt (book-value) to total asset (market-value) ratio (the variable, $\mathrm{D} / \mathrm{V}(t+1)$ ). The total market-value asset here is total book-value asset minus shareholders' equity (book-value) plus market capitalization of the firm.

Next, we use four independent variables: our explanatory variables are as follows. First, 1) EOH denotes the number of shares held by the board of the directors to the total shares issued at the end of the fiscal year. Second, 2) OWN denotes the number of shares held by the 10 largest shareholders to the total shares issued at the end of the fiscal year. Third, 3) DGCH denotes the number of shares held by the domestic non-financial corporations to the total shares issued at the end of the fiscal year. Finally, 4) FCH denotes the number of shares held by foreign companies to the total shares issued at the end of the fiscal year.

As for the other explanatory variables, we employ two sets of controlling variables. 1) Our first set includes SIZE, PPE/A, M/B, and EBITDA/A. Explaining in order, SIZE denotes the market capitalization of the firm, $\mathrm{PPE} / \mathrm{A}$ denotes the ratio of the amount of tangible fixed assets minus depreciations to total assets, and $\mathrm{M} / \mathrm{B}$ is the total market-value asset to total book-value asset ratio. Total market-value asset here is total book-value asset minus shareholders' equity (book-value) plus market capitalization of the firm. Moreover, EBITDA/A is the earnings before interest, taxes, depreciation, and amortization (EBITDA) to total book-value asset ratio. Further, 2) our second set of controlling variables includes $\log \mathrm{S}, \log \mathrm{A}, \mathrm{DP} / \mathrm{A}$, and DIV/BE. Explaining in order, $\log \mathrm{S}$ denotes the logarithm of sales and $\log$ A denotes the logarithm of total asset (book-value). In addition, DP/A denotes the depreciation to total asset (book-value) ratio and DIV/BE means the yearly dividend amount to shareholders' equity (book-value) ratio. All controlling variables employed in this paper follow the study of Baker and Wurgler (2002). 
For the analyses of our panel data, this paper utilizes several models. The first model is for testing the next year's total debt (book-value) to total asset (book-value) ratio, $\mathrm{D} / \mathrm{A}(t+1)$, with the first set of controlling variables:

$$
D_{i, t+1} / A_{i, t+1}=\varsigma_{i, 0}+\varsigma_{i, 1} O_{\text {WNER }}+\varsigma_{i, 2} S I Z E_{i, t}+\varsigma_{i, 3} P P E_{i, t} / A_{i, t}+\varsigma_{i, 4} M_{i, t} / B_{i, t}+\varsigma_{i, 5} E B I T D A_{i, t} / A_{i, t}+\tau_{i, t+1} .
$$

Next, the second model is to test the next year's total debt (book-value) to total asset (book-value) ratio with the second set of controlling variables:

$$
D_{i, t+1} / A_{i, t+1}=\eta_{i, 0}+\eta_{i, 1} O W N E R_{i, t}+\eta_{i, 2} \log S_{i, t}+\eta_{i, 3} \log A_{i, t}+\eta_{i, 4} D P_{i, t} / A_{i, t}+\eta_{i, 5} D I V_{i, t} / B E_{i, t}+\kappa_{i, t+1} .
$$

Further, the third model is to test the next year's total debt (book-value) to total asset (market-value) ratio, $\mathrm{D} / \mathrm{V}(t+1)$, with the first set of controlling variables as the following pooled regression (3):

$$
D_{i, t+1} / V_{i, t+1}=\xi_{i, 0}+\xi_{i, 1} O W N E R_{i, t}+\xi_{i, 2} S I Z E_{i, t}+\xi_{i, 3} P P E_{i, t} / A_{i, t}+\xi_{i, 4} M_{i, t} / B_{i, t}+\xi_{i, 5} E B I T D A_{i, t} / A_{i, t}+v_{i, t+1} .
$$

The final model is to test the next year's total debt (book-value) to total asset (market-value) ratio with the second set of controlling variables as the following pooled regression (4):

$$
D_{i, t+1} / V_{i, t+1}=u_{i, 0}+l_{i, 1} O W N E R_{i, t}+l_{i, 2} \log S_{i, t}+l_{i, 3} \log A_{i, t}+i_{i, 4} D P_{i, t} / A_{i, t}+u_{i, 5} D I V_{i, t} / B E_{i, t}+v_{i, t+1} .
$$

In models (1) to (4), the expression of OWNER in our regressions means the variable, EOH, OWN, DGCH, and FCH. Namely, we implement these regressions by exchanging the variable expressed as OWNER for EOH, OWN, DGCH, and FCH, respectively. As we mentioned, we test these four models by balanced and unbalanced panel regressions.

Table 1. The descriptive statistics as to the balanced panel data regarding the corporations in the Nikkei 225 in Japan: Statistical characteristics from the fiscal year of 1986 to 2011

\begin{tabular}{llllllll}
\hline & $\mathrm{D} / \mathrm{A}(t+1)$ & $\mathrm{D} / \mathrm{V}(t+1)$ & $\mathrm{SIZE}$ & $\mathrm{PPE} / \mathrm{A}$ & $\mathrm{M} / \mathrm{B}$ & $\mathrm{EBITDA} / \mathrm{A}$ & $\operatorname{logS}$ \\
\hline Mean & 0.532 & 0.390 & 0.977 & 0.239 & 1.612 & 0.087 & 26.811 \\
Median & 0.530 & 0.366 & 0.567 & 0.202 & 1.431 & 0.083 & 26.819 \\
Std. Dev. & 0.192 & 0.201 & 1.537 & 0.167 & 0.683 & 0.043 & 1.304 \\
Skewness & -0.135 & 0.404 & 7.059 & 1.319 & 2.594 & 0.476 & -0.109 \\
CS obs. & 107 & 107 & 107 & 107 & 107 & 107 & 107 \\
TS obs. & 26 & 26 & 26 & 26 & 26 & 26 & 26 \\
Panel obs. & 2782 & 2782 & 2782 & 2782 & 2782 & 2782 & 2782 \\
\hline & $\log \mathrm{A}$ & $\mathrm{DP} / \mathrm{A}$ & $\mathrm{DIV} / \mathrm{BE}$ & EOH & OWN & DGCH & FCH \\
\hline Mean & 27.215 & 0.032 & 0.023 & 0.764 & 38.142 & 13.807 & 17.553 \\
Median & 27.160 & 0.030 & 0.020 & 0.102 & 35.753 & 11.110 & 15.081 \\
Std. Dev. & 0.996 & 0.020 & 0.012 & 2.015 & 62.733 & 9.425 & 12.533 \\
Skewness & 0.289 & 0.614 & 2.215 & 4.674 & 51.294 & 1.744 & 1.152 \\
CS obs. & 107 & 107 & 107 & 107 & 107 & 107 & 107 \\
TS obs. & 26 & 26 & 26 & 26 & 26 & 26 & 26 \\
Panel obs. & 2782 & 2782 & 2782 & 2782 & 2782 & 2782 & 2782
\end{tabular}

Notes: Descriptive statistics as to the variables regarding the corporations in the Nikkei 225 index in Japan are shown in this table. The statistics are computed for the panel data (balanced) for the period from 1986 to 2011. In the table, D/A $(t+1)$ denotes the next year's total debt (book-value) to total asset (book-value) ratio and $\mathrm{D} / \mathrm{V}(t+1)$ denotes the next year's total debt (book-value) to total asset (market-value) ratio. Total market-value asset here is total book-value asset minus shareholders' equity (book-value) plus market capitalization of the firm. Further, SIZE denotes the market capitalization of the firm, PPE/A denotes the ratio of the amount of tangible fixed asset minus depreciations to total asset, and M/B is the total market-value asset to total book-value asset ratio. Again, total market-value asset is total book-value asset minus shareholders' equity (book-value) plus market capitalization of the firm. Moreover, EBITDA/A is the EBITDA to total book-value asset ratio, $\log \mathrm{S}$ means the logarithm of sales, and $\log \mathrm{A}$ denotes the logarithm of total asset. In addition, DP/A denotes the depreciations to total asset (book-value) ratio and DIV/BE is the yearly dividend amount to shareholders' equity (book-value) ratio. Further, EOH denotes the number of shares held by the board of the directors to the total shares issued at the end of the fiscal year, OWN denotes the number of shares held by the 10 largest shareholders to the total shares issued at the end of the fiscal year, DGCH denotes the number of shares held by the domestic non-financial corporations to the total shares issued at the end of the fiscal year, and FCH denotes the number of shares held by foreign companies to the total shares issued at the end of the fiscal year. Furthermore, as to the statistic values, 'Std. Dev.' means the each variable's standard deviation. With respect to the number of samples, 'Panel obs.', 'CS obs.', and 'TS obs.' denote the numbers of the panel data, the cross-sectional data, and the time-series data, respectively. 
Table 2. The relations between corporate ownership and the next year's capital structure measured by the total book-value debt ratio to the total book-value asset ratio: Evidence from the unbalanced panel regressions for the firms in the Nikkei 225

\begin{tabular}{|c|c|c|c|c|c|c|c|c|}
\hline & Model 1 & Model 2 & Model 3 & Model 4 & Model 5 & Model 6 & Model 7 & Model 8 \\
\hline Const. & $0.625 * * *$ & $0.625 * * *$ & $0.599 * * *$ & $0.696^{* * *}$ & $-0.528 * * *$ & $-0.596 * * *$ & $-0.715^{* * *}$ & $-0.922 * * *$ \\
\hline$p$-value & 0.000 & 0.000 & 0.000 & 0.000 & 0.000 & 0.000 & 0.000 & 0.000 \\
\hline $\mathrm{EOH}$ & -0.0001 & & & & $-0.004^{* * *}$ & & & \\
\hline$p$-value & 0.872 & & & & 0.000 & & & \\
\hline OWN & & $-0.0001 *$ & & & & $-0.0003 *$ & & \\
\hline$p$-value & & 0.089 & & & & 0.062 & & \\
\hline DGCH & & & $0.002 * * *$ & & & & $0.002 * * *$ & \\
\hline$p$-value & & & 0.000 & & & & 0.000 & \\
\hline $\mathrm{FCH}$ & & & & $-0.004 * * *$ & & & & $-0.007 * * *$ \\
\hline$p$-value & & & & 0.000 & & & & 0.000 \\
\hline SIZE & $-0.007 * * *$ & $-0.005^{* * *}$ & $-0.005 * * *$ & $-0.004 * * *$ & & & & \\
\hline$p$-value & 0.000 & 0.000 & 0.000 & 0.000 & & & & \\
\hline $\mathrm{PPE} / \mathrm{A}$ & $0.412 * * *$ & $0.417 * * *$ & $0.411 * * *$ & $0.342 * * *$ & & & & \\
\hline$p$-value & 0.000 & 0.000 & 0.000 & 0.000 & & & & \\
\hline $\mathrm{M} / \mathrm{B}$ & 0.0003 & 0.0002 & $-3.5 \mathrm{E}-05$ & $6.5 \mathrm{E}-04 *$ & & & & \\
\hline$p$-value & 0.380 & 0.431 & 0.904 & 0.070 & & & & \\
\hline EBITDA/A & $-1.541 * * *$ & $-1.537 * * *$ & $-1.580 * * *$ & $-1.459 * * *$ & & & & \\
\hline$p$-value & 0.000 & 0.000 & 0.000 & 0.000 & & & & \\
\hline $\log S$ & & & & & $0.039^{* * *}$ & $0.036^{* * *}$ & $0.035^{* * *}$ & $0.032 * * *$ \\
\hline$p$-value & & & & & 0.000 & 0.000 & 0.000 & 0.000 \\
\hline $\log A$ & & & & & 0.003 & 0.008 & $0.012 * *$ & $0.028 * * *$ \\
\hline$p$-value & & & & & 0.607 & 0.128 & 0.015 & 0.000 \\
\hline $\mathrm{DP} / \mathrm{A}$ & & & & & $-0.918 * * *$ & $-0.690 * * *$ & $-0.804 * * *$ & $-1.464 * * *$ \\
\hline$p$-value & & & & & 0.000 & 0.000 & 0.000 & 0.000 \\
\hline $\mathrm{DIV} / \mathrm{BE}$ & & & & & 1.072 & 1.124 & 1.328 & $2.042 * * *$ \\
\hline$p$-value & & & & & 0.202 & 0.182 & 0.143 & 0.001 \\
\hline $\operatorname{Adj} . R^{2}$ & 0.265 & 0.265 & 0.276 & 0.323 & 0.097 & 0.098 & 0.113 & 0.280 \\
\hline Obs.(Panel) & 4788 & 4809 & 4809 & 4803 & 4448 & 4475 & 4489 & 4441 \\
\hline
\end{tabular}

Notes: The evidence from the unbalanced panel data analyses regarding the debt ratio determinants of the corporations in the Nikkei 225 stock index in Japan is shown in this table. The sample period spans from 1986 to 2011 . The dependent variable in this table is the following year's total debt (book-value) to total asset (book-value) ratio. With regard to the independent variables, SIZE means the market capitalization of the firm, PPE/A denotes the ratio of the amount of tangible fixed assets minus depreciations to total assets, and M/B is the total market-value asset to total book-value asset ratio. Total market-value asset here is total book-value asset minus shareholders' equity (book-value) plus market capitalization of the firm. Moreover, EBITDA/A denotes the EBITDA to total book-value asset ratio, $\operatorname{logS}$ is the logarithm of sales, and $\log$ A denotes the logarithm of total asset. In addition, DP/A denotes the depreciation to total asset (book-value) ratio and DIV/BE means the yearly dividend amount to shareholders' equity (book-value) ratio. Further, EOH denotes the number of shares held by the board of the directors to the total shares issued at the end of the fiscal year, OWN denotes the number of shares held by the 10 largest shareholders to the total shares issued at the end of the fiscal year, DGCH denotes the number of shares held by the domestic non-financial corporations to the total shares issued at the end of the fiscal year, and FCH denotes the number of shares held by foreign companies to the total shares issued at the end of the fiscal year. Furthermore, Obs. (Panel) denotes the number of pooled data; Adj. $R^{2}$ means the value of the adjusted $R$-squared. Moreover, ***,**, and * denote the statistically significant coefficients at the $1 \%$ level, $5 \%$ level, and $10 \%$ level, respectively. 
Table 3. The relations between corporate ownership and the next year's capital structure measured by the total book-value debt ratio to the total market-value asset ratio: Evidence from the unbalanced panel regressions for the firms in the Nikkei 225

\begin{tabular}{|c|c|c|c|c|c|c|c|c|}
\hline & Model 1 & Model 2 & Model 3 & Model 4 & Model 5 & Model 6 & Model 7 & Model 8 \\
\hline Const. & $0.528 * * *$ & $0.526 * * *$ & $0.505^{* * *}$ & $0.554 * * *$ & $-1.066 * * *$ & $-1.133 * * *$ & $-1.209 * * *$ & $-1.358 * * *$ \\
\hline$p$-value & 0.000 & 0.000 & 0.000 & 0.000 & 0.000 & 0.000 & 0.000 & 0.000 \\
\hline $\mathrm{EOH}$ & $-0.003 * * *$ & & & & $-0.007 * * *$ & & & \\
\hline$p$-value & 0.001 & & & & 0.000 & & & \\
\hline OWN & & -0.0001 & & & & $-0.0003 *$ & & \\
\hline$p$-value & & 0.190 & & & & 0.095 & & \\
\hline DGCH & & & $0.001 * * *$ & & & & $0.002 * * *$ & \\
\hline$p$-value & & & 0.000 & & & & 0.000 & \\
\hline $\mathrm{FCH}$ & & & & $-0.002 * *$ & & & & $-0.005^{* * *}$ \\
\hline$p$-value & & & & 0.027 & & & & 0.000 \\
\hline SIZE & $-0.012 * * *$ & $-0.010 * * *$ & $-0.010 * * *$ & $-0.010 * * *$ & & & & \\
\hline$p$-value & 0.000 & 0.000 & 0.000 & 0.000 & & & & \\
\hline $\mathrm{PPE} / \mathrm{A}$ & $0.410 * * *$ & $0.423 * * *$ & $0.419 * * *$ & $0.393 * * *$ & & & & \\
\hline$p$-value & 0.000 & 0.000 & 0.000 & 0.000 & & & & \\
\hline $\mathrm{M} / \mathrm{B}$ & -0.001 & -0.001 & -0.002 & -0.001 & & & & \\
\hline$p$-value & 0.163 & 0.169 & 0.122 & 0.230 & & & & \\
\hline EBITDA/A & $-2.034 * * *$ & $-2.059 * * *$ & $-2.092 * * *$ & $-2.028 * * *$ & & & & \\
\hline$p$-value & 0.000 & 0.000 & 0.000 & 0.000 & & & & \\
\hline $\log S$ & & & & & $0.022 * * *$ & $0.021 * * *$ & $0.020 * * *$ & $0.018 * * *$ \\
\hline$p$-value & & & & & 0.000 & 0.000 & 0.000 & 0.000 \\
\hline $\log \mathrm{A}$ & & & & & $0.036^{* * *}$ & $0.039 * * *$ & $0.042 * * *$ & $0.053 * * *$ \\
\hline$p$-value & & & & & 0.000 & 0.000 & 0.000 & 0.000 \\
\hline $\mathrm{DP} / \mathrm{A}$ & & & & & $-1.507 * * *$ & $-1.452 * * *$ & $-1.557 * * *$ & $-1.899 * * *$ \\
\hline$p$-value & & & & & 0.000 & 0.000 & 0.000 & 0.000 \\
\hline DIV/BE & & & & & $-0.895^{*}$ & -0.886 & -0.750 & -0.274 \\
\hline$p$-value & & & & & 0.100 & 0.114 & 0.226 & 0.539 \\
\hline $\operatorname{Adj} . R^{2}$ & 0.355 & 0.355 & 0.360 & 0.363 & 0.132 & 0.123 & 0.128 & 0.202 \\
\hline Obs.(Panel) & 4788 & 4809 & 4809 & 4803 & 4426 & 4449 & 4451 & 4438 \\
\hline
\end{tabular}

Notes: The evidence from the unbalanced pooled regressions in connection with the debt ratio determinants as to the corporations in the Nikkei 225 stock index in Japan is shown in this table. The sample period spans from 1986 to 2011 (fiscal year). The dependent variable in this table is the following year's total debt (book-value) to total asset (market-value) ratio. Regarding the independent variables, SIZE means the market capitalization of the firm, PPE/A denotes the ratio of the amount of tangible fixed assets minus depreciations to total assets, and $\mathrm{M} / \mathrm{B}$ is the total market-value asset to total book-value asset ratio. Total market-value asset here is total book-value asset minus shareholders' equity (book-value) plus market capitalization of the firm. Moreover, EBITDA/A means the EBITDA to total book-value asset ratio, $\operatorname{logS}$ is the logarithm of sales, and $\log \mathrm{A}$ denotes the logarithm of total asset. In addition, DP/A denotes the depreciation to total asset (book-value) ratio and DIV/BE means the yearly dividend amount to shareholders' equity (book-value) ratio. Further, EOH denotes the number of shares held by the board of the directors to the total shares issued at the end of the fiscal year, OWN denotes the number of shares held by the 10 largest shareholders to the total shares issued at the end of the fiscal year, DGCH denotes the number of shares held by the domestic non-financial corporations to the total shares issued at the end of the fiscal year, and FCH denotes the number of shares held by foreign companies to the total shares issued at the end of the fiscal year. Furthermore, Obs. (Panel) denotes the number of pooled data and $A d j . R^{2}$ denotes the value of the adjusted $R$-squared. In addition, ${ }^{* *},{ }^{* *}$, and * indicate the statistically significant coefficients at the $1 \%$ level, $5 \%$ level, and $10 \%$ level, respectively. 
Table 4. The relations between corporate ownership and the next year's capital structure measured by the total book-value debt ratio to the total book-value asset ratio: Evidence from the balanced panel regressions for the firms in the Nikkei 225

\begin{tabular}{|c|c|c|c|c|c|c|c|c|}
\hline & Model 1 & Model 2 & Model 3 & Model 4 & Model 5 & Model 6 & Model 7 & Model 8 \\
\hline Const. & $0.596 * * *$ & $0.601 * * *$ & $0.567 * * *$ & $0.690^{* * *}$ & $-0.942 * * *$ & $-0.924 * * *$ & $-1.076 * * *$ & $-1.263 * * *$ \\
\hline$p$-value & 0.000 & 0.000 & 0.000 & 0.000 & 0.000 & 0.000 & 0.000 & 0.000 \\
\hline $\mathrm{EOH}$ & $0.006 * * *$ & & & & 0.001 & & & \\
\hline$p$-value & 0.004 & & & & 0.426 & & & \\
\hline OWN & & $-3.89 \mathrm{E}-05^{*}$ & & & & $-0.0001 * * *$ & & \\
\hline$p$-value & & 0.098 & & & & 0.002 & & \\
\hline DGCH & & & $0.002 * * *$ & & & & $0.003 * * *$ & \\
\hline$p$-value & & & 0.000 & & & & 0.000 & \\
\hline $\mathrm{FCH}$ & & & & $-0.004 * * *$ & & & & $-0.007 * * *$ \\
\hline$p$-value & & & & 0.000 & & & & 0.000 \\
\hline SIZE & -0.002 & -0.002 & -0.002 & $0.003 * *$ & & & & \\
\hline$p$-value & 0.426 & 0.210 & 0.374 & 0.031 & & & & \\
\hline $\mathrm{PPE} / \mathrm{A}$ & $0.435 * * *$ & $0.426 * * *$ & $0.424 * * *$ & $0.349^{* * *}$ & & & & \\
\hline$p$-value & 0.000 & 0.000 & 0.000 & 0.000 & & & & \\
\hline $\mathrm{M} / \mathrm{B}$ & -0.014 & -0.013 & -0.013 & $-0.015^{*}$ & & & & \\
\hline$p$-value & 0.244 & 0.298 & 0.274 & 0.068 & & & & \\
\hline EBITDA/A & $-1.709 * * *$ & $-1.687 * * *$ & $-1.673 * * *$ & $-1.688 * * *$ & & & & \\
\hline$p$-value & 0.000 & 0.000 & 0.000 & 0.000 & & & & \\
\hline $\log S$ & & & & & $0.036^{* * *}$ & $0.036^{* * *}$ & $0.031 * * *$ & $0.026^{* * *}$ \\
\hline$p$-value & & & & & 0.000 & 0.000 & 0.000 & 0.000 \\
\hline $\log \mathrm{A}$ & & & & & $0.020 * *$ & $0.018 * *$ & $0.027 * * *$ & $0.046^{* * *}$ \\
\hline$p$-value & & & & & 0.013 & 0.016 & 0.000 & 0.000 \\
\hline $\mathrm{DP} / \mathrm{A}$ & & & & & $-0.742 * * *$ & $-0.734 * * *$ & $-0.604 * * *$ & $-1.456 * * *$ \\
\hline$p$-value & & & & & 0.000 & 0.000 & 0.000 & 0.000 \\
\hline $\mathrm{DIV} / \mathrm{BE}$ & & & & & 0.516 & 0.560 & 1.050 & $1.414^{*}$ \\
\hline$p$-value & & & & & 0.634 & 0.606 & 0.367 & 0.074 \\
\hline $\operatorname{Adj} . R^{2}$ & 0.263 & 0.259 & 0.271 & 0.328 & 0.117 & 0.119 & 0.143 & 0.303 \\
\hline Obs.(Panel) & 2782 & 2782 & 2782 & 2782 & 2782 & 2782 & 2782 & 2782 \\
\hline
\end{tabular}

Notes: The evidence from the balanced pooled regressions in connection with the debt ratio determinants as to the corporations in the Nikkei 225 stock index in Japan is shown in this table. The sample period spans from 1986 to 2011 (fiscal year). The dependent variable in this table is the following year's total debt (book-value) to total asset (book-value) ratio. With respect to the independent variables, SIZE means the market capitalization of the firm, PPE/A denotes the ratio of the amount of tangible fixed assets minus depreciations to total assets, and M/B is the total market-value asset to total book-value asset ratio. Total market-value asset here is total book-value asset minus shareholders' equity (book-value) plus market capitalization of the firm. Moreover, EBITDA/A denotes the EBITDA to total book-value asset ratio, $\operatorname{logS}$ is the logarithm of sales, and $\log \mathrm{A}$ denotes the logarithm of total asset. In addition, DP/A denotes the depreciation to total asset (book-value) ratio and DIV/BE means the yearly dividend amount to shareholders' equity (book-value) ratio. Further, EOH denotes the number of shares held by the board of the directors to the total shares issued at the end of the fiscal year, OWN denotes the number of shares held by the 10 largest shareholders to the total shares issued at the end of the fiscal year, DGCH denotes the number of shares held by the domestic non-financial corporations to the total shares issued at the end of the fiscal year, and FCH denotes the number of shares held by foreign companies to the total shares issued at the end of the fiscal year. Furthermore, Obs. (Panel) denotes the number of pooled data; Adj. $R^{2}$ denotes the value of the adjusted $R$-squared. Moreover, ***,**, and * indicate the statistically significant coefficients at the $1 \%$ level, $5 \%$ level, and $10 \%$ level, respectively. 
Table 5. The relations between corporate ownership and the next year's capital structure measured by the total book-value debt ratio to the total market-value asset ratio: Evidence from the balanced panel regressions for the firms in the Nikkei 225

\begin{tabular}{|c|c|c|c|c|c|c|c|c|}
\hline & Model 1 & Model 2 & Model 3 & Model 4 & Model 5 & Model 6 & Model 7 & Model 8 \\
\hline Const. & $0.622 * * *$ & $0.626 * * *$ & $0.598 * * *$ & $0.666 * * *$ & $-1.532 * * *$ & $-1.550 * * *$ & $-1.678^{* * *}$ & $-1.785 * * *$ \\
\hline$p$-value & 0.000 & 0.000 & 0.000 & 0.000 & 0.000 & 0.000 & 0.000 & 0.000 \\
\hline $\mathrm{EOH}$ & $0.004 * *$ & & & & $-0.003 * *$ & & & \\
\hline$p$-value & 0.034 & & & & 0.026 & & & \\
\hline OWN & & $-3.8 \mathrm{E}-05^{* *}$ & & & & $-0.0001 * * *$ & & \\
\hline$p$-value & & 0.026 & & & & 0.007 & & \\
\hline DGCH & & & $0.002 * * *$ & & & & $0.003 * * *$ & \\
\hline$p$-value & & & 0.000 & & & & 0.000 & \\
\hline $\mathrm{FCH}$ & & & & $-0.002 * * *$ & & & & $-0.005 * * *$ \\
\hline$p$-value & & & & 0.000 & & & & 0.000 \\
\hline SIZE & 0.001 & 0.0001 & 0.001 & $0.003 *$ & & & & \\
\hline$p$-value & 0.683 & 0.940 & 0.651 & 0.096 & & & & \\
\hline PPE/A & $0.345^{* * *}$ & $0.338 * * *$ & $0.336^{* * *}$ & $0.303 * * *$ & & & & \\
\hline$p$-value & 0.000 & 0.000 & 0.000 & 0.000 & & & & \\
\hline $\mathrm{M} / \mathrm{B}$ & $-0.108 * * *$ & $-0.107^{* * *}$ & $-0.107^{* * *}$ & $-0.108^{* * *}$ & & & & \\
\hline$p$-value & 0.000 & 0.000 & 0.000 & 0.000 & & & & \\
\hline EBITDA/A & $-1.664 * * *$ & $-1.647 * * *$ & $-1.636^{* * *}$ & $-1.650 * * *$ & & & & \\
\hline$p$-value & 0.000 & 0.000 & 0.000 & 0.000 & & & & \\
\hline $\log S$ & & & & & $0.014^{* * *}$ & $0.013 * * *$ & $0.009^{* * *}$ & $0.006^{* *}$ \\
\hline$p$-value & & & & & 0.000 & 0.000 & 0.002 & 0.037 \\
\hline $\log A$ & & & & & $0.060 * * *$ & $0.061 * * *$ & $0.068 * * *$ & $0.080 * * *$ \\
\hline$p$-value & & & & & 0.000 & 0.000 & 0.000 & 0.000 \\
\hline $\mathrm{DP} / \mathrm{A}$ & & & & & $-1.272 * * *$ & $-1.243 * * *$ & $-1.132 * * *$ & $-1.743 * * *$ \\
\hline$p$-value & & & & & 0.000 & 0.000 & 0.000 & 0.000 \\
\hline $\mathrm{DIV} / \mathrm{BE}$ & & & & & $-1.593 * *$ & $-1.533 * *$ & -1.117 & $-0.948 *$ \\
\hline$p$-value & & & & & 0.020 & 0.023 & 0.131 & 0.075 \\
\hline $\operatorname{Adj} . R^{2}$ & 0.452 & 0.451 & 0.458 & 0.464 & 0.158 & 0.159 & 0.174 & 0.238 \\
\hline Obs.(Panel) & 2782 & 2782 & 2782 & 2782 & 2782 & 2782 & 2782 & 2782 \\
\hline
\end{tabular}

Notes: The evidence from the balanced pooled regressions in connection with the debt ratio determinants as to the corporations in the Nikkei 225 stock index in Japan is shown in this table. The sample period spans from 1986 to 2011 (fiscal year). The dependent variable in this table is the following year's total debt (book-value) to total asset (market-value) ratio. With respect to the independent variables, SIZE means the market capitalization of the firm, PPE/A denotes the ratio of the amount of tangible fixed assets minus depreciations to total assets, and M/B means the total market-value asset to total book-value asset ratio. Total market-value asset here is total book-value asset minus shareholders' equity (book-value) plus market capitalization of the firm. Moreover, EBITDA/A denotes the EBITDA to total book-value asset ratio, logS means the logarithm of sales, and $\log \mathrm{A}$ denotes the logarithm of total asset. In addition, DP/A denotes the depreciation to total asset (book-value) ratio and DIV/BE means the yearly dividend amount to shareholders' equity (book-value) ratio. Further, EOH denotes the number of shares held by the board of the directors to the total shares issued at the end of the fiscal year, OWN denotes the number of shares held by the 10 largest shareholders to the total shares issued at the end of the fiscal year, DGCH denotes the number of shares held by the domestic non-financial corporations to the total shares issued at the end of the fiscal year, and FCH denotes the number of shares held by foreign companies to the total shares issued at the end of the fiscal year. Furthermore, Obs. (Panel) denotes the number of pooled data; Adj. $R^{2}$ denotes the value of the adjusted $R$-squared. Moreover, $* * *, * *$, and $*$ denote the statistically significant coefficients at the $1 \%$ level, $5 \%$ level, and $10 \%$ level, respectively.

\section{Empirical Evidence and the Interpretations}

This section documents our data characteristics, empirical results, and their interpretations. The descriptive statistics as to our variables regarding the firms in the Nikkei 225 stock index in Japan are firstly displayed in Table 1. They are the statistics as to the pooled firm data; the sample period spans from 1986 to 2011 (fiscal year). Table 1 enables us to survey the statistical data characteristics. As Table 1 shows, in the case of the balanced panel, the numbers of the stacked data are in time-series, 26-years, in cross-section, 107, and 2782 pooled data in total. 
Next, we show the results from our unbalanced pooled regressions with regard to the linkage between equity ownership and the following year's first type of corporate leverage (calculated as the total book-value liability to the total book-value asset ratio) and the relationship between equity ownership and the following year's second type of corporate leverage (calculated as the total book-value liability to the total market-value asset ratio) in Tables 2 and 3, respectively. Moreover, in Tables 4 and 5, the estimation results from our balanced pooled regressions regarding the linkage between equity ownership and the following year's first type of corporate leverage (calculated as the total book-value liability to the total book-value asset ratio) and the relationship between equity ownership and the following year's second type of corporate leverage (calculated as the total book-value liability to the total market-value asset ratio) are respectively displayed. We firstly understand from Tables 2 and 3 that the relations between debt ratios and the shareholding ratios of foreign companies (FCH) are statistically significantly negative, and the relations are very strong. Second, we also understand that the relations between debt ratios and the shareholding ratios of the domestic non-financial corporations (DGCH) are statistically significantly positive, and the relations are also very strong. Third, the relations between debt ratios and the shareholding ratios of the 10 largest shareholders $(\mathrm{OWN})$ are negative although the relations are not so statistically robust in our case of the unbalanced panel analyses. Finally, the relations between debt ratios and the shareholding ratios of board of the directors $(\mathrm{EOH})$ are negative, and the relations are not perfectly statistically significant in our case of the unbalanced panel analyses.

Further, from the evidence shown in Tables 4 and 5, it is firstly understood that the relations between debt ratios and the shareholding ratios of foreign companies (FCH) are again statistically significantly negative, and the relations are very strong. Second, we also understand that the relations between debt ratios and the shareholding ratios of the domestic non-financial corporations $(\mathrm{DGCH})$ are statistically significantly positive, and the relations are again very strong. Third, the relations between debt ratios and the shareholding ratios of the 10 largest shareholders $(\mathrm{OWN})$ are negative, and the relations are statistically significant in the case of the balanced panel. Finally, the relations between debt ratios and the shareholding ratios of board of the directors (EOH) are unclear in our case of the balanced panel analyses.

Next is the interpretation of our results. First, the strong negative relations between debt ratios and the shareholding ratios of foreign companies $(\mathrm{FCH})$ would mean that foreign companies choose the firms whose financial strengths are high. This evidence would be also because of the stronger outside governance effect in our context. Second, the strong positive relations between debt ratios and the shareholding ratios of the domestic non-financial corporations (DGCH) would imply that high cross-shareholding companies' financial strengths from the viewpoint of capital adequacy are not high. This evidence would also indicate the weaker outside corporate governance in such firms in our context. Third, although not strong but generally negative relations between debt ratios and the shareholding ratios of the 10 largest shareholders $(\mathrm{OWN})$ would indicate that the firms whose ownership is largely shared by the stable shareholders have relatively high capital adequacy ratio; hence we cannot affirm that the corporate governance is weak in companies highly owned by the stable shareholders. Finally, the unclear relations between debt ratios and the shareholding ratios of board of the directors $(\mathrm{EOH})$ would show the unclearness of larger shareholdings by executives for the effective corporate management and governance.

\section{Summary and Conclusions}

This study explored the linkage between equity ownership and the corporate debt ratios of the firms in the Nikkei 225 stock index in Japan. We firstly clarified that 1) the relations between debt ratios and the shareholding ratios of foreign companies were strongly negative. Second, we revealed that 2) the relations between debt ratios and the shareholding ratios of the domestic non-financial corporations were strongly positive. Third, we also found that 3) the relations between debt ratios and the shareholding ratios of the 10 largest shareholders were generally negative. Finally, we derived that 4) the relations between debt ratios and the shareholding ratios of board of the directors were unclear. As our evidence shows, the corporate equity ownership shall be one of the significant determinants of the capital structure in Japan. Therefore, we consider that investigating other ownership factors by using broader samples may be our future another work.

\section{Acknowledgements}

We thank the kind financial support from the Japan Society for the Promotion of Science to our research. Furthermore, we are particularly grateful for the repeated kind article invitation from this journal. Moreover, I also thank the Editor and anonymous referees for their kind comments to this paper.

\section{References}

Baker, M., \& Wurgler, J. (2002). Market timing and capital structure. Journal of Finance, 57, 1-32. 
http://dx.doi.org/10.1111/1540-6261.00414

Brailsford, T. J., Oliver, B. R., \& Pua, S. L. H. (2002). On the relation between ownership structure and capital structure. Accounting and Finance, 42, 1-26. http://dx.doi.org/10.1111/1467-629X.00001

Himmelberg, C. P. H., Hubbard, R. G., \& Palia, D. (1999). Understanding the determinants of managerial ownership and the link between ownership and performance. Journal of Financial Economics, 53, 353-384. http://dx.doi.org/10.1016/S0304-405X(99)00025-2

Jensen, M. C., \& Meckling, W. H. (1976). Theory of the firm: Managerial behavior, agency costs and ownership structure. Journal of Financial Economics, 3, 305-360. http://dx.doi.org/10.1016/0304-405X(76)90026-X

King, M. R., \& Santor, E. (2008). Family values: Ownership structure, performance and capital structure of Canadian firms. Journal of Banking \& Finance, 32, 2423-2432. http://dx.doi.org/10.1016/j.jbankfin.2008.02.002

McConnell, J. J., \& Servaes, H. (1990). Additional evidence on equity ownership and corporate value. Journal of Financial Economics, 27, 595-612. http://dx.doi.org/10.1016/0304-405X(90)90069-C

Morck, R., Shleifer, A., \& Vishny, R. W. (1988). Management ownership and market valuation: An empirical analysis. Journal of Financial Economics, 20, 293-315. http://dx.doi.org/10.1016/0304-405X(88)90048-7

Shleifer, A., \& Vishny, R. W. (1986). Large shareholders and corporate control. Journal of Political Economy, 94, 461-488. http://dx.doi.org/10.1086/261385

Short, H., Keasey, K., \& Duxbury, D. (2002). Capital structure, management ownership and large external shareholders: a UK analysis. International Journal of the Economics of Business, 9, 375-399. http://dx.doi.org/10.1080/1357151021000010382

\section{Copyrights}

Copyright for this article is retained by the author(s), with first publication rights granted to the journal.

This is an open-access article distributed under the terms and conditions of the Creative Commons Attribution license (http://creativecommons.org/licenses/by/3.0/). 